Research Paper

\title{
Prophylactic cranial irradiation in resected small cell lung cancer: A systematic review with meta-analysis
}

\author{
Yang Yang, Danhong Zhang, Xia Zhou, Wuan Bao, Yonglin Ji, Liming Sheng, Lei Cheng, Ying Chen, \\ Xianghui Du, Guoqin Qiu ${ }^{\bowtie}$ \\ Department of Radiation Therapy, Zhejiang Cancer Hospital, Hangzhou, China; Zhejiang Key Laboratory of Radiation Oncology, Hangzhou 310022, China. \\ $\square$ Corresponding author: Guoqin Qiu, Department of Radiation Therapy, Zhejiang Cancer Hospital, Hangzhou, China; Zhejiang Key Laboratory of Radiation \\ Oncology, NO. 38 of Guang ji Road, Hangzhou 310022, China. Tel: +86-571-88128182; Email: qiuguoqinzjcc@163.com. \\ (c) Ivyspring International Publisher. This is an open access article distributed under the terms of the Creative Commons Attribution (CC BY-NC) license \\ (https:// creativecommons.org/licenses/by-nc/4.0/). See http://ivyspring.com/terms for full terms and conditions.
}

Received: 2017.06.14; Accepted: 2017.12.05; Published: 2018.01.01

\begin{abstract}
Background: The use of $\mathrm{PCl}$ in early operable patients with small cell lung cancer (SCLC) is still controversial. Therefore, we conducted a systematic review with meta-analysis to investigate the effects of $\mathrm{PCl}$ in resected SCLC patients.

Methods: Relevant studies were identified from PubMed and EMBASE databases, the pooled hazard risks were obtained by the random-effects model. We also analyzed the brain metastasis (BM) risk in p-stage I patients without $\mathrm{PCl}$.

Results: Five retrospective studies were identified and a total of 1691 patients were included in our analysis, 315 of them received $\mathrm{PCl}$. For all the resected patients, $\mathrm{PCl}$ was associated with improved overall survival (HR: $0.52,95 \% \mathrm{Cl}: 0.33-0.82$ ), and reduced brain metastasis risk (RR: $0.50,95 \% \mathrm{Cl}$ : $0.32-0.78$ ). However, with regard to $\mathrm{P}$-stage I patients, no survival benefit was brought by $\mathrm{PCl}$ (HR: 0.87, 95\% Cl: 0.34-2.24). Moreover, the pooled analysis of 7 studies found that the 5-year brain metastasis risk was relatively low $(12 \%, 95 \% \mathrm{Cl}: 8 \%-17 \%)$ for $\mathrm{p}$-stage I patients without $\mathrm{PCl}$.

Conclusions: $\mathrm{PCl}$ might be associated with a favorable survival advantage and reduced $\mathrm{BM}$ risk in complete resected SCLC patients, except for p-stage I patients.
\end{abstract}

Key words: small cell lung cancer; surgery; PCI; radiotherapy; meta-analysis

\section{Introduction}

Small cell lung carcinoma accounts for $15 \%$ of lung cancer, and the prognosis is poor. Concurrent chemotherapy is the standard treatment modality in limited-stage disease. Moreover, about $50 \%$ patients will finally improve brain metastasis during the course of their disease [1].

PCI has been regarded as a part of standard care for all SCLC patients in complete remission after initial treatment, including chemoradiotherapy, RT and CRT, since the meta-analysis published in 1999[2]. The meta-analysis found that PCI could not only significantly reduce the BM incidence, but also was associated with improved disease-free survival and overall survival, compared with the control group. The findings have been then confirmed by other following clinical studies [3-6]. Now, the guideline has recommended that PCI should be conducted in the SCLC patients who have good responses to the first-line treatment, including complete remission and partial remission [7]. However, the patients in most studies received chemotherapy or thoracic radiation therapy as initial treatment.

Surgery has a minor role in the SCLC treatment, for those early-staged SCLC, including T1 3N0M0[8, 9]. However, in clinical practice, whether to perform PCI for those resected patients is still not well answered, especially for stage I patients T1-2N0M0[10, 11], since the recommendation of PCI was based on the meta-analysis of patients received 
chemotherapy combined with thoracic radiotherapy. In fact, several retrospective studies have long ago noticed that BM incidence was relatively lower in those operable p-stage I SCLC patients, and questioned the validity of $\mathrm{PCI}$ in those patients [12-15]. Then very recently, two clinical studies from China reported that $\mathrm{p}$-stage II-III might gain benefits from PCI but not for p-stage I SCLC patients $[16,17]$. However, all these studies were retrospective studies with small number of samples, which limited the reliability of the conclusion.

Since few patients have undergone surgery, random clinical trials are difficult to be carried out, to resolve the role of PCI in resected SCLC. Therefore, we conducted a systematic review with meta-analysis on the effect of PCI in resected SCLC patients, to increase the statistical power of the results and provide more evidence for clinical decision.

\section{Methods}

\section{Publication selection}

Relevant studies were identified from PubMed databases from 1956 to December 2016, the key words were 'small cell lung cancer' or 'SCLC' combined with 'PCI' or 'prophylactic cranial irradiation'. We did not use 'resection' or 'surgery' as key words, to maximize the results. Our literature selection was limited in English. References in the identified publications were also reviewed to find more relevant studies.

\section{Inclusion criteria}

To be included in our meta-analysis, the studies should meet the following criteria: 1) the research objects were SCLC patients received complete resection as the initial treatment for primary tumor; 2) the intervention approach was PCI, 3) The endpoints included overall survival (OS), progression free survival(PFS) and brain metastasis rate; 4) quantitative data on the effect of PCI on the endpoints can be obtained. We also included the studies describing the $\mathrm{BM}$ rates in the stage I patients without PCI.

\section{Data extraction}

We extracted the following information from each included article: author's name, publication year, accrual duration, follow-up time, number of total patients, number of patients received PCI, patients stage and treatment methods. For survival analysis, HR (hazard ratio) is the most proper statistic to analyze time-event outcomes, which takes both the number and timing of events into consideration. Thus, the multivariable adjusted HR with its $95 \%$ CIs was extracted from each original study. However, in some studies, HRs were not reported while
Kaplan-Meier survival curves were presented. In this situation, HRs were calculated from data, which were obtained from the survival curves using Engauge Digitizer version 2.11 (free software downloaded from http://sourceforge.net), according to the methods described previously [18].

\section{Statistical methods}

The heterogeneity across studies was evaluated by the Cochran's $\mathrm{Q}$ and $I^{2}$ statistics, $\mathrm{P}<0.10$ was considered to be statistically significant [19]. In the case, the random effects model was used to pool the individual HR estimates [20], otherwise, the fixed-effects model was employed. The $\mathrm{BM}$ rates were calculated with the variance stabilizing double arcsine transformation[21], and then were pooled by the inverse variance heterogeneity model[22], thus, studies with incidence of zero could be included in the analysis, and negative lower 95\% confidence intervals were avoided[23]. Results were back-transformed to natural proportions, for ease of interpretation.

A sensitivity analysis was carried out to examine the stability of the results, in which each study was removed. Publication was investigated by Egger test, $\mathrm{P}<0.1$ was considered as statistically significant [24]. Meta-analysis of HRs and sensitivity analysis were performed using STA TA12.0 software (Stata Corporation, College Station, TX, USA), and individual rates were pooled using $\mathrm{R}$ Version 3.3.2 (https://www.r-project.org/).

\section{Results}

\section{Study selection and patient characteristics}

In total, and 4 retrospective studies concerning on the effect of PCI on overall survival of complete resected SCLC were included, no random clinical trials were identified. In addition, 6 studies described the BM incidence in the resected SCLC patients without PCI [12, 14-17, 25]. The flowchart of study selection was shown in Figure 1 and the main characteristics of included studies were shown in Table 1.

The patient number ranged from 154 to 954 . All patients were histologically confirmed small cell lung cancer, and underwent surgical resection as initial treatment. The pathological stages ranged from I-IV, most patients also received adjuvant therapy, including chemotherapy, thoracic irradiation or chemoradiation. Only a small part of patients $(17.80 \%)$ underwent PCI. The irradiation dose was between 25Gy/10F to 30Gy/10f.

To our knowledge, Ichinose Y, firstly in 1989 reported the $\mathrm{BM}$ rate in patients underwent surgical resection, $18 \%(2 / 11)$ p-stage I developed brain 
metastasis, however, brain CT/ MRI were not used in clinical practice, some patients might have subclinical lesions before treatment [25]. Several subsequent studies reported much lower BM rates in p-stage I, compared to II/III patients, including 3 studies from Japan [12, 14, 26], and 1 study from China[15], suggesting that PCI might be omitted for patients with p-stage I SCLC.

In 2007, Bischof, et al. explored the effect of PCI on the survival in 39 surgically treated patients with p-stages I and II [27]. They found that brain metastasis-free survival $(p=0.01)$ and overall survival $(p=0.01)$ were improved significantly in $p$ stage I-II resected patients who received $\mathrm{PCI}$, the incidence of $\mathrm{BM}$ was $22 \%(4 / 18)$ and $0.0 \%(0 / 21)$ in the groups without PCI or after PCI, the authors concluded that PCI should be suggested for those surgically treated patients, since they might be also considered in complete remission. However, the authors did not conduct sub-group analysis in p-stage I patients, duo to a small number of sample.

Then, one retrospective study from China by Zhu $\mathrm{H}$, et, al in 2014 showed that no survival benefit was brought from PCI in p-stage I disease, and the 3 -year BM rate was only $9.7 \%[16]$. Up to now, the largest study using the National Cancer Data Base (NCDB), including 954 patients, found that PCI after surgery and adjuvant chemotherapy was associated with better survival in p-stage I patients, and provides further evidence to support NCCN recommendations on PCI. However, the major limitations of the study included selection bias, confounding variables,

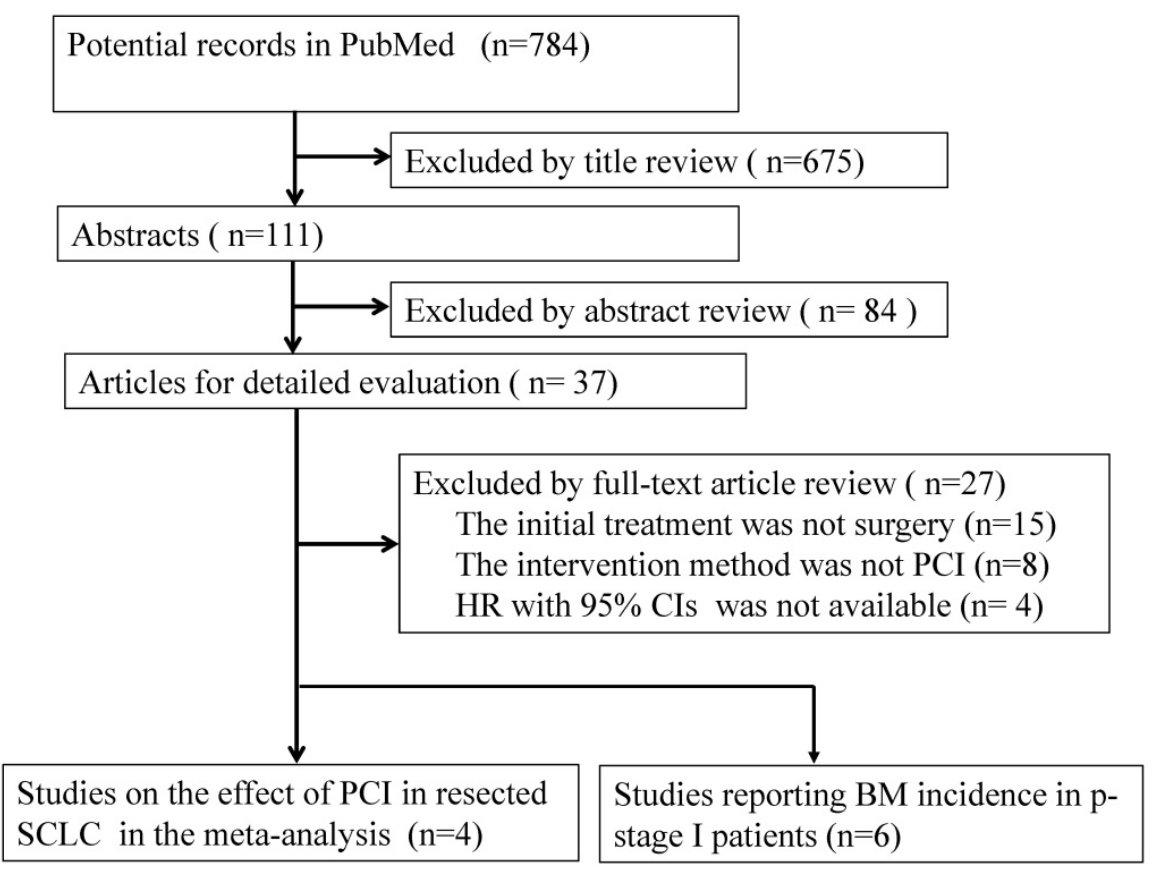

Figure 1. Flow chart of literature search in the meta-analysis inaccurate staging, lack of brain imaging and no data on chemotherapy $[28,29]$. Recently, Xu, J, et al. drew different conclusions in 954 patients with completely resected pT1-2N0M0 SCLC, they found that PCI was associated with a significant survival advantage in patients with completely resected SCLC, but not in patients stage I disease[17].

\section{Over Survival}

There were 4 studies $[16,17,28,30]$ involving the data of PCI on the survival. HR cannot be acquired for the study by Bischof, et.al [27]. However, 3 studies included all the patients who received complete resection, one study [28] only included p-stage I patients, which was thus removed from our analysis. Combined analysis by random-effects model showed that the pooled HR was 0.52 (95\% CI: 0.33-0.82), with a moderate heterogeneity $\left(I^{2}=48.4 \%\right.$, P-heterogeneity= $0.14)$, indicating that $\mathrm{PCI}$ might improve OS in resected SCLC patients (Figure 2).

To solve the dispute on the role of PCI in p-stage I SCLC patients, we further conducted subgroup analysis. 2 studies directly provided the HRs on the effect of PCI on OS in p-stage I SCLC patients [17, 28], another HR was calculated from the Kaplan-Meier survival curve in the study by Zhu H, et al [16]. After combining all the results, the summary HR was 0.87 (95\% CI: 0.34-2.24), with a substantial heterogeneity $\left(I^{2}=65.7 \%\right.$, P-heterogeneity $\left.=0.05\right)$ (Figure 3$)$.

\section{Brain metastasis}

Three studies $[16,17,30]$ reported the data of brain metastasis rate comparing patients with PCI to patients without PCI during the follow-up. Our analysis of the 3 studies yielded a pooled RR of 0.50 (95\% CI: 0.32-0.78), with no heterogeneity ( $\mathrm{I}^{2}=0.0 \%$, P-heterogeneity $=0.40)$, suggesting that PCI might reduce the $\mathrm{BM}$ incidence significantly in SCLC patients after complete surgery (Figure 4).

With respect to the effect of PCI on BM rate in the p-stage I patients, no enough data can be obtained. Only one study by $\mathrm{Xu} \mathrm{J}$ et, al. reported that the frequency of $\mathrm{BM}$ was $10.5 \%(2 / 19)$ in the PCI-treated group while $13.6 \%$ $(8 / 59)$ patients in the non-PCI group developed $\mathrm{BM}$, and the difference between the two groups was not significant $(\mathrm{P}=0.38)[17]$. 
Table 1. Characteristics of studies included in the meta-analysis on the effect of $\mathrm{PCl}$ on overall survival in resected SCLC

\begin{tabular}{|c|c|c|c|c|c|c|c|c|c|c|}
\hline $\begin{array}{l}\text { Author } \\
\text { [Ref] }\end{array}$ & Year & Country & Design & $\begin{array}{l}\text { Accrual } \\
\text { years }\end{array}$ & Follow-up time & $\begin{array}{l}\text { Total } \\
\text { Patients }\end{array}$ & PCI (\%) & Stage & PCI dose & Adjuvant chemotherapy \\
\hline $\begin{array}{l}\text { Bischof } \\
{[27]}\end{array}$ & 2007 & Germany & Retrospective & 1995-2006 & 29 (2-110) months & 39 & $21(54.0 \%)$ & p-stage IA-IIB & $30 \mathrm{~Gy} / 15 \mathrm{~F}$ & $\begin{array}{l}35(90.0 \%) \text { received } \geq 4 \\
\text { cycles of ChT }\end{array}$ \\
\hline $\begin{array}{l}\text { Zhu } \\
\mathrm{H}[16]\end{array}$ & 2014 & China & Retrospective & 2003-2009 & $\begin{array}{l}39.4(4.0-96.8) \\
\text { months }\end{array}$ & 193 & $67(34.7 \%)$ & c-stage I-III & $25 \mathrm{~Gy} / 10 \mathrm{~F}$ & $\begin{array}{l}\text { All the patients received } \\
\text { ChT, } 164(85.0 \%) \text { patients } \\
\text { received } \geq 4 \text { cycles of ChT }\end{array}$ \\
\hline $\begin{array}{l}\text { Yokouc } \\
\text { hi [30] }\end{array}$ & 2015 & Japan & Retrospective & 2003-2013 & $\begin{array}{l}25.5(0.4-130.9) \\
\text { months }\end{array}$ & 156 & $13(8.3 \%)$ & c-stage I-III & $\begin{array}{l}25 \mathrm{~Gy} / 10 \mathrm{~F} \text { or } \\
30 \mathrm{~Gy} / 15 \mathrm{~F}\end{array}$ & $\begin{array}{l}100(64.1 \%) \text { received } \\
\text { chemotherapy }\end{array}$ \\
\hline $\mathrm{Xu} \mathrm{J[17]}$ & 2016 & China & Retrospective & 2006-2014 & Not reported & 349 & $\begin{array}{l}115 \\
(32.9 \%)\end{array}$ & c-stage I-III & Not reported & $\begin{array}{l}290(83.1 \%) \text { received } \geq 4 \\
\text { cycles of ChT }\end{array}$ \\
\hline $\begin{array}{l}\text { Yang } \\
\text { C[28] }\end{array}$ & 2016 & USA & Retrospective & 2003-2011 & Not reported & 954 & $99(10.3 \%)$ & p-stage I & Not reported & $\begin{array}{l}566(59.3 \%) \text { received } \\
\text { chemotherapy }\end{array}$ \\
\hline
\end{tabular}

$\begin{array}{llllll}\text { Author } & \text { Year } \mathrm{T} & \mathrm{P} & \mathrm{HR}(95 \% \mathrm{Cl}) & \text { Weight(\%) }\end{array}$

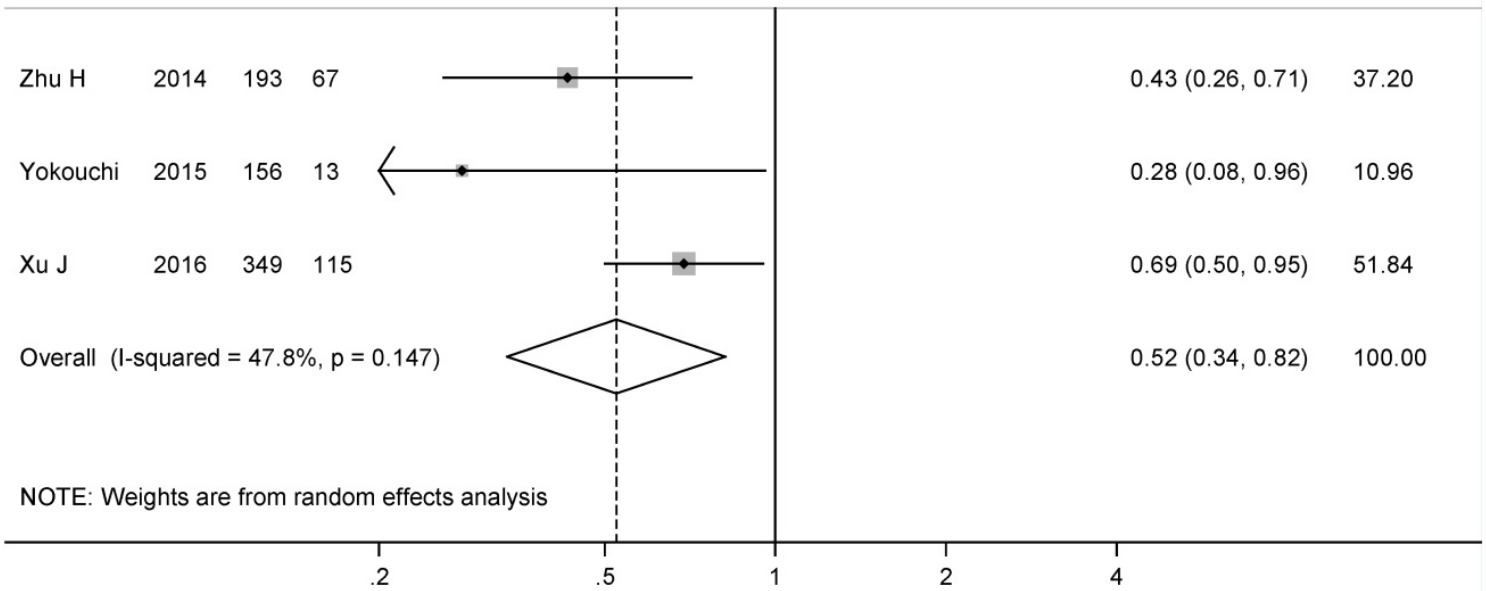

Figure 2. Forest plot of the effect of $\mathrm{PCl}$ on the overall survival in all SCLC patients with complete resection. (T: number of total patients; $\mathrm{P}$ : number of patients with $\mathrm{PCl}$ )

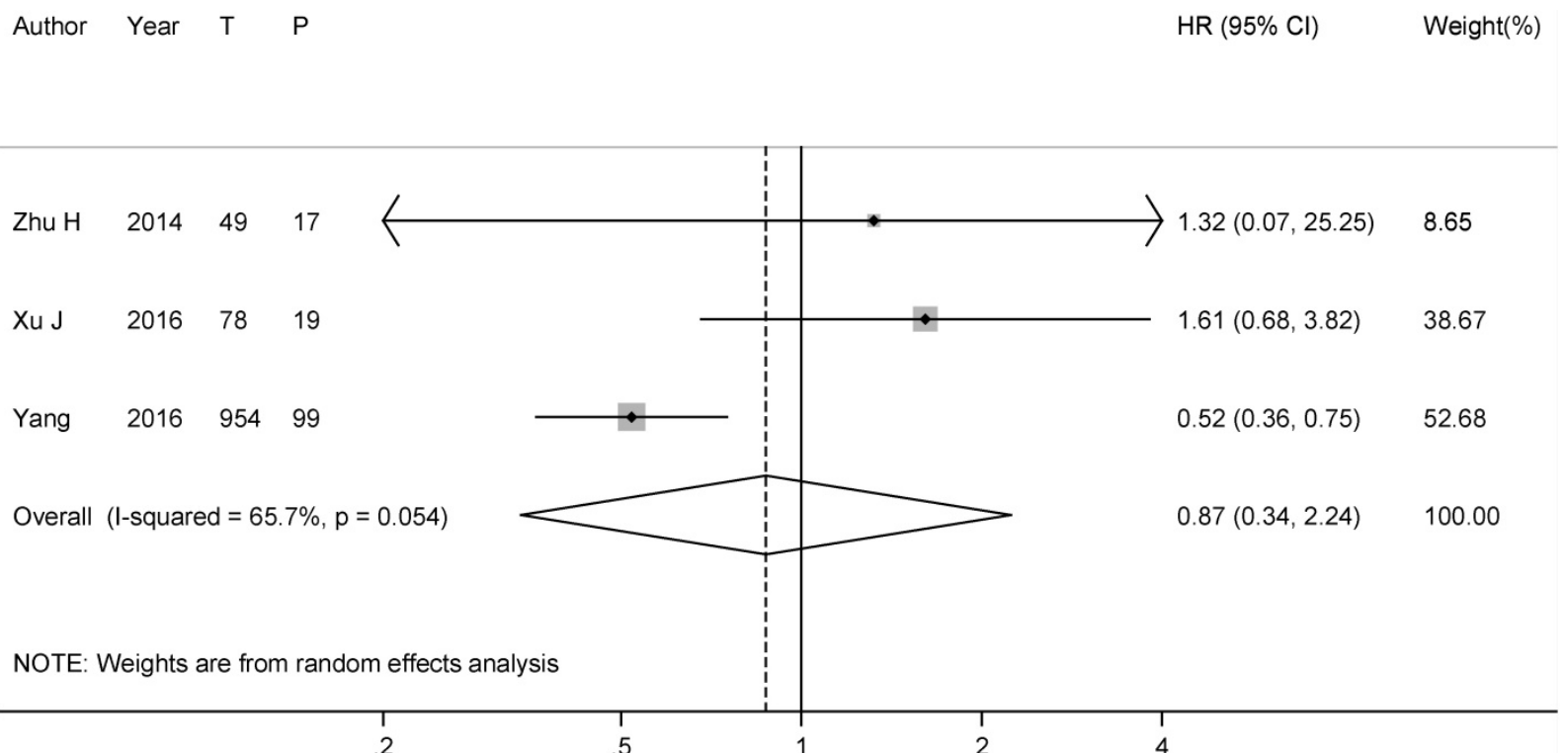

Figure 3. Forest plot of relative risk of $\mathrm{PCl}$ on the overall survival in resected p-stage I SCLC patients. (T: number of total patients; $\mathrm{P}$ : number of patients with $\mathrm{PCl}$ ) 


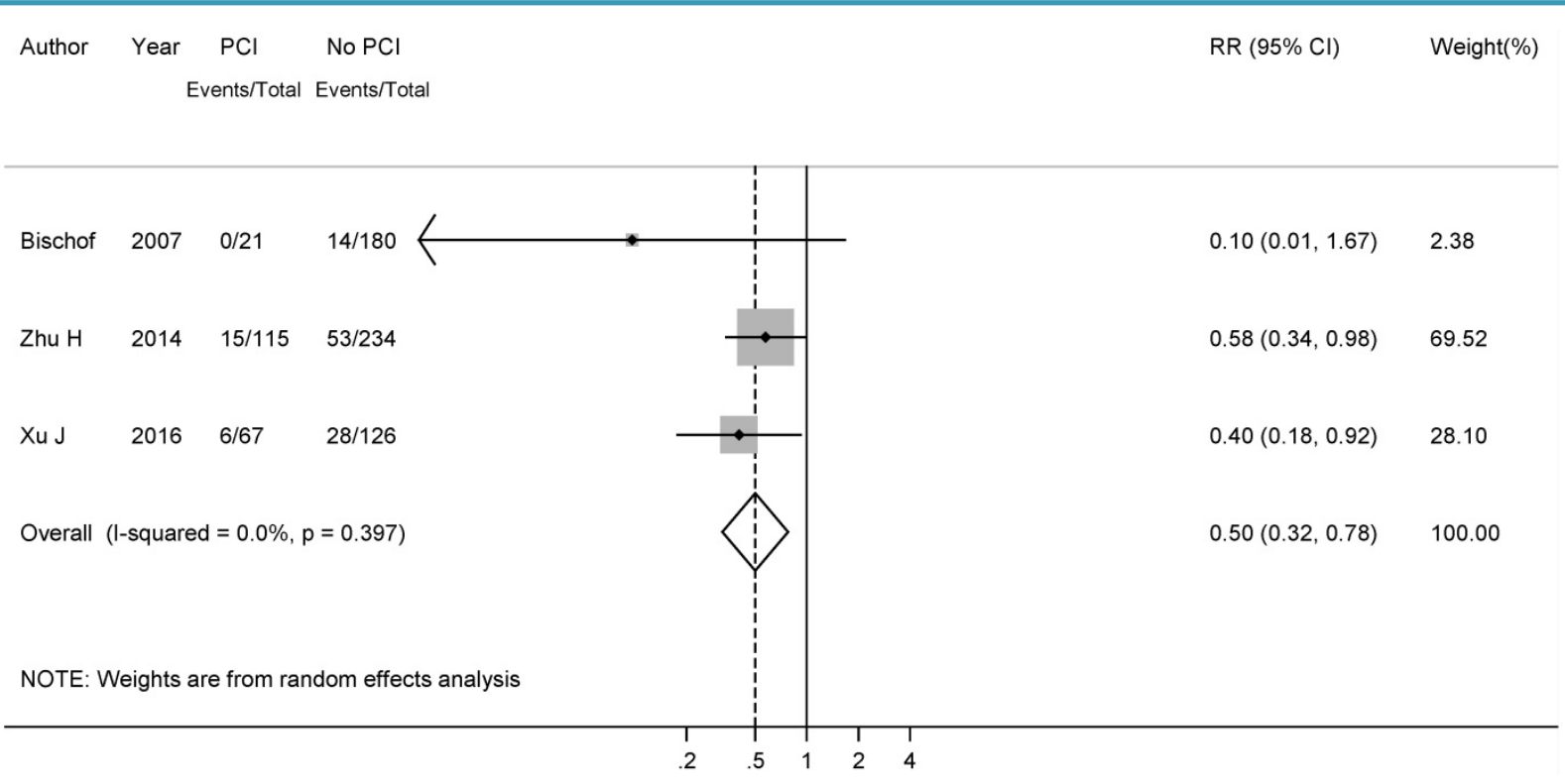

Figure 4. Forest plot of relative risks for brain metastasis in all resected SCLC patients.

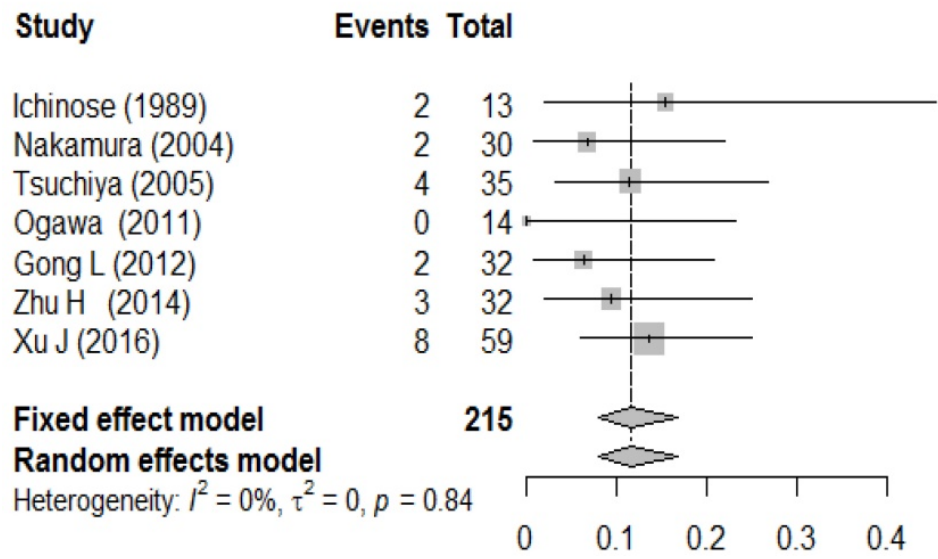

Proportion $\quad 95 \%-\mathrm{Cl} \quad$ (fixed) (random)

$0.15[0.02 ; 0.45] \quad 9.5 \% \quad 9.5 \%$

$0.07[0.01 ; 0.22] \quad 10.7 \% \quad 10.7 \%$

$0.11[0.03 ; 0.27] \quad 18.3 \% \quad 18.3 \%$

$0.00[0.00 ; 0.23] \quad 2.2 \% \quad 2.2 \%$

$0.06[0.01 ; 0.21] \quad 10.7 \% \quad 10.7 \%$

$0.09[0.02 ; 0.25] \quad 14.5 \% \quad 14.5 \%$

$0.14[0.06 ; 0.25] \quad 33.9 \% \quad 33.9 \%$

$0.12[0.08 ; 0.17] 100.0 \%$

$0.12[0.08 ; 0.17] \quad--100.0 \%$

Figure 5. Forest plot of the brain metastasis rate in resected SCLC patients without PCI.

To better explore the role of PCI in p-stage I SCLC patients, we further conducted a meta-analysis of BM incidence in p-stage I SCLC patients who did not undergo PCI. A total of 6 studies reported the BM incidence in those populations. $\mathrm{Wu}$, A. J.et al. recently reported that the 5-year cumulative incidence of brain metastasis for stage I/II and III were $12 \%$ and $26 \%$ in a review of 283 patients, which was not included in our analysis, since the BM rates of I and II stage patients were combined together[31]. After combining all the results, a low metachronous $\mathrm{BM}$ incidence $(0.12,95 \%$ CI: 0.08-0.17) was observed, with no heterogeneity $\left(\mathrm{I}^{2}=0.0 \%\right.$, P-heterogeneity $\left.=0.79\right)$ (Figure 5).

\section{Sensitivity analysis and Publication bias}

Sensitivity analysis showed that the pooled HRs were not changed significantly, when one study was removed and the rest were analyzed, which supported the reliability of our results. Since the small number of the studies included, publication bias was not evaluated by Egger's test or Begg's test. However, the funnel plot on the BM incidence seemed symmetrical (Supplementary Figure 1), indicating that there was no significant publication bias in the meta-analysis.

\section{Discussion}

According to our knowledge, this is the first meta-analysis concerning the influence of PCI on the survival in resected SCLC patients. Our results indicated that PCI might provide benefits for those complete resected SCLC patients as a whole, however, for p-stage I patients, PCI seemed to be useless for improving OS, since the BM incidence was relatively low in those patients.

Surgery can be an option for very early limited-stage SCLC, especially clinical stage I. 
(T1-2N0) SCLC patients. However, the role of PCI in those patients has not been investigated sufficiently, due to the small number of patients involved [32]. The controversy has been lasted to very recently, favorers insisted that $\mathrm{R} 0$ resection can be considered as a special form of complete remission, and thus PCI is also suitable for those patients [33], opponents argued that BM incidence was quite low in these early-stage patients, and neurological effects brought by PCI might outweigh its possible benefits [10]. The focus of the debate is the value of PCI in p-stage I patients. Basing on the published clinical studies, our results indicated that PCI might improve $\mathrm{OS}$ and reduce $\mathrm{BM}$ rate significantly in the complete SCLC patients.

To resolve the debate in p-stage I patients, our subgroup analysis showed that PCI was not associated with longer OS in this group. Only one study reported the difference of BM rates between PCI-group and non-PCI group, which found the result was non-significant. Therefore, we further performed a quantitative meta-analysis of BM incidence rates in p-stage I patients, and the results revealed that approximately $10 \%$ of p-stage I SCLC patients developed brain metastasis, indicating that no survival advantage obtained from PCI in p-stage I SCLC patients might be caused by the low incidence of BM in this population, and our result was similar to one brief report by Eze, C, et al [29]. In fact, previous studies found the BM rate in advanced-stage NSCLC was even higher (18-25\%), and PCI did not improve OS or DFS, although decreased the risk of $\mathrm{BM}[34,35]$. Therefore, PCI is not recommended as routine treatments for those patients, since cranial irradiation is potentially associated with a higher risk neurocognitive injury [36], which might overweight the potential benefits from PCI.

However, some shortcomings must be admitted in our meta-analysis. Firstly, since only few SCLC patients undergo surgical resection, there are still no random clinical studies to investigate the use of PCI in those patients. The studies included in our meta-analysis are retrospective studies with a small number of patients, which are prone to recall and selection bias. However, low heterogeneity was observed in our study, indicating the consistency among original studies. Secondly, lack of individual patient data limited our further analysis, especially the relative risks of 2-year OS and 5-year OS, also more subgroup analyses stratified by age, ethnicity, pathological stage and use of chemotherapy were not performed, Lastly, only publications in English were included, and meeting abstracts, trial registries, and articles in other languages were not retrieved, possible publication bias was inevitable.
Surgical resection is also recommended by the current guideline for early-stage small cell lung cancer, however, rigorous examinations before surgery including thoracic CT, PET/CT, brain MRI are necessary [37]. Although our results did not support the routine employment of PCI in pT1-2N0M0 stage SCLC patients, the decision of individual treatments must be established by the multidisciplinary team discussion and adequate communication with patients. For those patients, close surveillance with brain MRI may be an alternative strategy.

\section{Conclusions}

In conclusion, our results suggest that PCI might be associated with a favorable survival advantaged and reduced BM risk in complete resected SCLC patients, except for $\mathrm{p}$-stage I patients. Given the small number of included studies, the finding should be further confirmed by well-designed random clinical trials.

\section{Abbreviations}

SCLC: small cell lung cancer; PCI: prophylactic cranial irradiation; CRT: concurrent chemoradiotherapy; OS: overall survival; HR: hazard ratio; BM: brain metastases.

\section{Supplementary Material}

Supplementary figure S1.

http://www.jcancer.org/v09p0433s1.pdf

\section{Acknowledgements}

This work was supported by the fund of Zhejiang Province Medical and Health Science and Technology Project (2015KYA034 and 2016RCB002), and the National Natural Science Foundation of China (No. 81702968).

\section{Ethics approval and consent to participate}

This work did not require any written patient consent. The ethics committee of Zhejiang Cancer Hospital approved this work.

\section{Authors' contributions}

Qiu GQ and Yang Y conceived and designed the study. Zhou X, Ji Y, Bao W, Yang Y, Zhang D, Cheng $\mathrm{L}$, Cheng $\mathrm{Y}$ participated in the literature identification and data collecting. Yang Y, Zhang DH and Qiu GQ analyzed data, and performed the statistical analysis. Sheng L, and Du X critically revised the manuscript. All authors commented on drafts of the paper and approved the final manuscript. 


\section{Competing Interests}

The authors have declared that no competing interest exists.

\section{References}

1. Arriagada R, Chevalier TL, Borie F, Riviere A, Chomy P, Monnet I, Tardivon A, Viader F, Tarayre M, Benhamou S: Prophylactic Cranial Irradiation for Patients with Small-Cell Lung Cancer in Complete Remission. JNCI: Journal of the National Cancer Institute. 1995; 87(3):183-190.

2. Auperin A, Arriagada R, Pignon JP, Le Pechoux C, Gregor A, Stephens RJ, Kristjansen PE, Johnson BE, Ueoka H, Wagner $\mathrm{H}$ et al: Prophylactic cranial irradiation for patients with small-cell lung cancer in complete remission. Prophylactic Cranial Irradiation Overview Collaborative Group. N Engl J Med. 1999; 341(7):476-484.

3. Giuliani M, Sun A, Bezjak A, Ma C, Le LW, Brade A, Cho J, Leighl NB, Shepherd FA, Hope AJ: Utilization of prophylactic cranial irradiation in patients with limited stage small cell lung carcinoma. Cancer. 2010; 116(24):5694-5699.

4. Meert AP, Paesmans M, Berghmans T, Martin B, Mascaux C, Vallot F, Verdebout JM, Lafitte JJ, Sculier JP: Prophylactic cranial irradiation in small cell lung cancer: a systematic review of the literature with meta-analysis. BMC Cancer. 2001; 14(1):1-7.

5. Patel S, Macdonald OK, Suntharalingam M: Evaluation of the use of prophylactic cranial irradiation in small cell lung cancer. Cancer. 2009; 5(4):842-850.

6. Schild SE, Foster NR, Meyers JP, Ross HI, Stella PJ, Garces YI, Olivier KR, Molina JR, Past LR, Adjei AA: Prophylactic cranial irradiation in small-cell lung cancer: Findings from a North Central Cancer Treatment Group Pooled Analysis. Annals of Oncology. 2012; 23(11):2919-2924.

7. NCCN clinical practice guidelines in oncology: small cell lung cancer. Version I. 2016; In. https:// www.nccn.org/professionals/physician_gls/f_guidelines. asp\#sclc; 2016

8. Takei H, Kondo H, Miyaoka E, Asamura H, Yoshino I, Date H, Okumura M, Tada H, Fujii Y, Nakanishi Y et al: Surgery for small cell lung cancer: a retrospective analysis of 243 patients from Japanese Lung Cancer Registry in 2004. Journal of thoracic oncology: official publication of the International Association for the Study of Lung Cancer. 2014; 9(8):1140-1145.

9. Takenaka T, Takenoyama M, Inamasu E, Yoshida T, Toyokawa G, Nosaki K, Hirai F, Yamaguchi M, Shimokawa M, Seto $\mathrm{T}$ et al: Role of surgical resection for patients with limited disease-small cell lung cancer. Lung cancer. 2015; 88(1):52-56.

10. Knisely J, Sharma R, Goenka A, Halthore A: PCI in resected small-cell lung cancer. Lancet Oncol. 2016; 17(10e):415.

11. Péchoux CL: PCI in resected small-cell lung cancer - Author's reply. Lancet Oncology. 2016; 17(10):e416.

12. Nakamura $\mathrm{H}$, Kato $\mathrm{Y}$, Kato $\mathrm{H}$ : Outcome of surgery for small cell lung cancer response to induction chemotherapy predicts survival. Thoracic \& Cardiovascular Surgeon. 2004; 52(4):206-210.

13. Ichinose $Y$ : Phase II trial of postoperative adjuvant cisplatin and etoposide in patients with completely resected stage I-IIIa small cell lung cancer: the Japan Clinical Oncology Lung Cancer Study Group Trial (JCOG9101). Journal of Thoracic \& Cardiovascular Surgery. 2005; 129(129):977-983.

14. Ogawa S, Horio $Y$, Yatabe $Y$, Fukui T, Ito S, Hasegawa $Y$, Mitsudomi T, Hida T: Patterns of recurrence and outcome in patients with surgically resected small cell lung cancer. International Journal of Clinical Oncology. 2012; 17(3):218-224.

15. Gong L, Wang OI, Zhao L, Yuan Z, Li R, Wang P: Factors affecting the risk of brain metastasis in small cell lung cancer with surgery: is prophylactic cranial irradiation necessary for stage I-III disease? International Journal of Radiation Oncology Biology Physics. 2013; 85(1):196-200.

16. Zhu H, Guo H, Shi F, Zhu K, Luo J, Liu X, Kong L, Yu J: Prophylactic cranial irradiation improved the overall survival of patients with surgically resected small cell lung cancer, but not for stage I disease. Lung cancer. 2014; 86(3):334-338.

17. Xu J, Yang H, Fu X, Jin B, Lou Y, Zhang Y, Zhang X, Zhong H, Wang H, Wu D et al: Prophylactic Cranial Irradiation for Patients with Surgically Resected Small Cell Lung Cancer. Journal of thoracic oncology: official publication of the International Association for the Study of Lung Cancer. 2017; 12(2):347-353.

18. Tierney JF, Stewart LA, Ghersi D, Burdett S, Sydes MR: Practical methods for incorporating summary time-to-event data into meta-analysis. Trials. 2007; $8: 16$.

19. Higgins JP, Thompson SG, Deeks JJ, Altman DG: Measuring inconsistency in meta-analyses. BMJ 2003; 327(7414):557-560

20. DerSimonian R LN: Meta-analysis in clinical trials. Control Clin Trials. 1986; 7(3):11.

21. Freeman MF, Tukey JW: Transformations Related to the Angular and the Square Root. 1950; 21:607-611.

22. Doi SA, Barendregt JJ, Khan S, Thalib L, Williams GM: Advances in the meta-analysis of heterogeneous clinical trials I: The inverse variance heterogeneity model. Contemp Clin Trials. 2015; 45(Pt A):130-138.
23. Barendregt JJ, Doi SA, Lee YY, Norman RE, Vos T: Meta-analysis of prevalence. J Epidemiol Community Health. 2013; 67(11):974-978.

24. Sterne JAC, Egger M: Funnel plots for detecting bias in meta-analysis: Guidelines on choice of axis. J Clin Epidemiol. 2001; 54(10):1046-1055.

25. Ichinose Y, Hara N, Ohta M, Motohiro A, Hata K, Yagawa K: Brain metastases in patients with limited small cell lung cancer achieving complete remission. Correlation with TNM staging. Chest. 1989; 96(6):1332-1335.

26. Tsuchiya R, Suzuki K, Ichinose Y, Watanabe Y, Yasumitsu T, Ishizuka N, Kato $\mathrm{H}$ : Phase II trial of postoperative adjuvant cisplatin and etoposide in patients with completely resected stage I-IIIa small cell lung cancer: the Japan Clinical Oncology Lung Cancer Study Group Trial (JCOG9101). The Journal of thoracic and cardiovascular surgery. 2005; 129(5):977-983.

27. Bischof M, Debus J, Herfarth K, Muley T, Kappes J, Storz K, Hoffmann H: Surgery and chemotherapy for small cell lung cancer in stages I-II with or without radiotherapy. Strahlentherapie und Onkologie: Organ der Deutschen Rontgengesellschaft [et al]. 2007; 183(12):679-684.

28. Yang CJ, Chan DY, Speicher PJ, Gulack BC, Wang X, Hartwig MG, Onaitis MW, Tong BC, D'Amico TA, Berry MF: Role of Adjuvant Therapy in a Population-Based Cohort of Patients with Early-Stage Small-Cell Lung Cancer. Journal of Clinical Oncology Official Journal of the American Society of Clinical Oncology. 2016; 34(10):1057-64.

29. Eze C, Roengvoraphoj O, Manapov F: Prophylactic Cranial Irradiation in Resected Early-Stage Small Cell Lung Cancer. International journal of radiation oncology, biology, physics. 2017; 98(3):612-614.

30. Yokouchi H, Ishida T, Yamazaki S, Kikuchi H, Oizumi S, Uramoto H, Tanaka F, Harada M, Akie K, Sugaya F: Prognostic impact of clinical variables on surgically resected small-cell lung cancer: Results of a retrospective multicenter analysis (FIGHT002A and HOT1301A). Lung cancer. 2015; 90(3):548-553.

31. Wu AJ, Gillis A, Foster A, Woo K, Zhang Z, Gelblum DY, Downey RJ, Rosenzweig KE, Ong L, Perez CA, et al: Patterns of failure in limited-stage small cell lung cancer: Implications of TNM stage for prophylactic cranial irradiation. Radiotherapy and oncology: journal of the European Society for Therapeutic Radiology and Oncology. 2017; 17:32478-7.

32. Pechoux CL, Sun A, Slotman BJ, De Ruysscher D, Belderbos I, Gore EM: Prophylactic cranial irradiation for patients with lung cancer. Lancet Oncol. 2016; 17(7e):277-293.

33. Le Pechoux C: PCI in resected small-cell lung cancer - Author's reply. Lancet Oncol. 2016; 17(10e):416

34. Gaspar LE, Chansky K, Albain KS, Vallieres E, Rusch V, Crowley JJ, Livingston RB, Gandara DR: Time from treatment to subsequent diagnosis of brain metastases in stage III non-small-cell lung cancer: a retrospective review by the Southwest Oncology Group. Journal of clinical oncology: official journal of the American Society of Clinical Oncology. 2005; 23(13):2955-2961.

35. Gore EM, Bae K, Wong SJ, Sun A, Bonner JA, Schild SE, Gaspar LE, Bogart JA, Werner-Wasik M, Choy H: Phase III comparison of prophylactic cranial irradiation versus observation in patients with locally advanced non-small-cell lung cancer: primary analysis of radiation therapy oncology group study RTOG 0214. Journal of clinical oncology: official journal of the American Society of Clinical Oncology. 2011; 29(3):272-278.

36. Sun A, Bae K, Gore EM, Movsas B, Wong SJ, Meyers CA, Bonner JA, Schild SE, Gaspar LE, Bogart JA: Phase III Trial of Prophylactic Cranial Irradiation Compared with Observation in Patients with Locally Advanced Non-Small-Cell Lung Cancer: Neurocognitive and Quality-of-Life Analysis. Journal of Clinical Oncology. 2011; 29(29):279-286.

37. Glatzer M, Rittmeyer A, Muller J, Opitz I, Papachristofilou A, Psallidas I, Fruh M, Born D, Putora PM: Treatment of limited disease small cell lung cancer: the multidisciplinary team. The European respiratory journal. 2017; 50(2). 